\title{
The Effect of Learning Model on Higher Order Thinking and Student Science Process Skills in Ecology
}

\author{
Haryati $^{1}$, Binari Manurung ${ }^{1}$, Tumiur Gultom ${ }^{1}$ \\ ${ }^{l}$ Department of Biology Education, Postgraduate Program, Universitas Negeri Medan, Jl. Willem Iskandar Psr \\ V Medan Estate-Indonesia (20221)
}

*Corresponding Author: Binari Manurung, Department of Biology Education, Postgraduate Program, Universitas Negeri Medan, Jl. Willem Iskandar Psr V Medan Estate-Indonesia (20221)

\begin{abstract}
This study aims to determine the effect of learning models on high-order thinking and science process skill of students at ecology topic in class X SMA Negeri 1 Kuala. The research applied experimental quasy method with 3 classes' choosed by using cluster random sampling technique. The class X-2 learn with Problem Based Learning, class X-4 with Guided Discovery, and while class X-1 with Direct Instruction models (control). The research instruments were learning outcome test in multiple choice form for higher order thinking and essay test for science process skills. The data analysis technique used Covariate Analysis (Anacova). The research results showed that there was significant effect of learning model on students' higher order thinking (Fcount $=4.371 ; P=0.039)$. The student higher order thinking that learn by Problem Based Learning $(86.55 \pm 4.0)$ was significantl highest than Guided Discovery $(83.83 \pm 3.3)$ and Direct Instruction models $(80.61 \pm 3.1)$. There was also significant effect of learning model on students' science process skill (Fcount $=6.106 ; P=0.015)$. The students' science process skills learn by Problem Based Learning $(85.50 \pm$ 4.2) was significant highest than Guided Discovery $(83.31 \pm 4.4)$ and Direct Instruction models $(81.26 \pm 3.1)$. The research result recommends the implementation of Problem Based Learning model in order to improve the higher order thinking and science process skills of the students at ecology topic in biology instruction.
\end{abstract}

Keywords: Problem Based Learning Learning, Guided Discovery, Higher-Order Thinking Skills, Science Process Skills.

\section{INTRODUCTION}

Indonesian students' scientific literacy based on PISA surveys started from 2000 to 2015 was always below the average score of OECD's countries. In the year 2000, Indonesia attained $38^{\text {th }}$ rank from 41 participant with mean score 393 and followed by $38^{\text {th }}$ rank from 40 participants with score 395 in 2003. It was getting worse in 2009 and 2012 , where Indonesia only able to reached $62^{\text {th }}$ and $64^{\text {th }}$ rank from 65 participant countries with 382 mean score. Meanwhile in 2015 , Indonesia attained $66^{\text {th }}$ rank from 72 participants (OECD, 2016; Manurung et al., 2017). These data showed that Indonesian students only achieve score about 400 constantly from year to years, which means students' scientific literacy still at the beginner level. If this situation is continiously happen, Indonesian students may have low in science process skills, critical and creative thinking, higher order thinking, science reflection and ultimately unable to survive in the era of globalization.

There are some factors that causes scientific literacy level of Indonesia students are still low. These factors could be viewed from the side of teacher, students and school condition where the the learning process take place. According to Samatowo (2010), learning process that be carried out by Indonesia teachers were mainly teacher-oriented. In this case, teacher used mainly direct instruction model in instruction. The students' tend to gain knowledge by remembering the simple fact (i.g. name, fact, term, simple formulation) (Rustaman, 2010) and students also were given less opportunity to develop their higher-order thinking skills. Aspects of analyzing, evaluating and creating that belongs to higher order thinking competence were done in the small part in learning process. Whereas, Heong, et al (2012) stated higher order thinking skill was indispensable for students to generate ideas so as to solve problems in learning process or in individual tasks. In addition, Chatib (2012) stated that high order thinking skills can help the students to achieve learning outcomes and to understand an informationIn order to improve the scientific literacy of Indonesia students, fundamentally many efforts have been 
done by goverment especially under the Minister of Education and Culture. Since 2013, there was the introduction of new curriculum for basic school, junior high school and senior high school. According to the new curriculum, learning process in natural science emphasizes scientific approach. It means in science instruction the teacher be suggested to use learning models based on scientific approach such as problem based learning, project based learning, contextual teaching learning, discovery or inquiry models (Kemdikbud, 2013 \& 2014). The increasing of higher order thingking and science process skills of the student basically could be done by some activities. These activieties includes the using some medias as ICT in learning proces, doing practicum on the field and in laboratory, using higher order thinking test and science process skill test in student assesment and especially by using some scientific approach in learning process (Masek \& Sulaiman, 2011; Abrari et al., 2012; Melani, 2012 and Noma et al., 2016).

According to Masek \& Sulaiman (2011), the implementation of problem based learning approach in learning process can make students to have higher-order thinking skills. Meyer et al. (2004) added, when students are able to think in higher order thinking, the students will master the science process skill. Furthermore, Slameto (2010) stated that problem based learning can influence student metacognition and increase the knowledge and science process sill of the students. Students who change their knowledge hence their skills and attitudes will also change.

In comparison to problem based learning, guided discovery is a learning model that leads students on activities that can develop student science process skills. In this case the students are guided to discover and investigate a science concept so that the knowledge and skills possessed by students are not the result of remembering a set of facts but based on their own findings. (Suryosubroto, 2002; Abrari, et al, 2012 ).

This study has been undertaken with the objective to know the effect of problem based learning, guided discovery and direct instruction models on higher order thinking competence and science process skill of Indonesia student at senior high school level (SMA) in biology instruction at topic ecology. It is hoped that the information obtained from this study will contribute and will be usefull for increasing the higher order thinking competence and science process skills of Indonesia students.

\section{Materials \& MethodS}

\subsection{Research Location, Population and Sample}

The research was conducted in SMA Negeri 1 Kuala that located at Jalan Perintis Kemerdekaan No. 3 Kuala. The investigation was done at even semester of academic year 2017/2018 and took place from February to April 2017. Research population was all student of class X, meanwhile its samples were class X1, X2 and X4 that be determined by cluster random sampling tehnique (Sugiyono, 2011).

\subsection{Research Variables and Design}

The independent variables of research was learning models that consisted of Problem Based Learning (PBL), Guided Discovery (GD) and Direct Instruction (DI). Class X1 was taught by direct instruction (control), class X2 by problem based learning and class X4 by guided discovery. Whereas, research dependent variable was higher order thinking (analysis, evaluation and creation) and science process skills that consisted of observation, classification, prediction, interpretation, questioning, hypothesizing, planning experiments, applying concepts and communicating. This study belongs to quasi experiments with non equivalent pretest-postest control group design.

\subsection{Instruments and Data Analysis}

Research instrument was student achievement test to obtain hihger order thinking data and science proces skill test for collecting science process skills data. Research data was analysed using analyses of covariance and followed by multiple comparison test of Scheffe. Kolmogorov-Smirnov test was used for testing normality of data, whereas, Leven's test for data homogenity. All data were analysed by using sofware SPSS version 22 .

\section{RESULTS \& DISCUSSION}

\subsection{Results}

The research data was mean of higher-order thinking skills and science process skills of the students in the class of problem based learning, guided discovery and direct instruction. The results of data processing showed that mean score of the higher order thinking and science process skill of students 
that taught by problem based learning and guided discovery classes were higher than in direct instruction class (control group). The mean score of higher order thinking in the problem-based learning, guided discovery and direct instruction classes were $86.55,83.83$ and 80.61 , respectively. Due to mean score of science process skill, it was 85.50 for problem based learning, 83.31 for guided discovery and 81.26 for direct instruction class.

Based on the above mean both for higher order thinking and science process skill abilities, it can be concluded that the highest learning outcomes was the class of problem-based learning model. Therefore, the using of problem-based learning model at ecology topic in biology instruction gave the best effect on higher order thinking and science process skills of the students.

Furthermore, based on the prerequisite analysis that has been done toward normality of higher order thingking and science process skill data, the results showed that both higher order thinking and science process skills data were normal (Table 1 and Table 2).

Table1. The result of normality test of higher order thinking data

\begin{tabular}{|c|l|c|c|}
\hline \multirow{2}{*}{ No } & \multicolumn{1}{|c|}{ Learning Model } & \multicolumn{2}{|c|}{ Kolmogorov-Smirnov } \\
\cline { 3 - 4 } & & Sig. & Note \\
\hline 1 & Problem Based Learning (PB) & 0.092 & Normal \\
\hline 2 & Guided Discovery (GD) & 0.200 & Normal \\
\hline 3 & Direct instruction (DI) & 0.074 & Normal \\
\hline
\end{tabular}

Table2. The result of normality test of science process skills data

\begin{tabular}{|c|l|c|c|}
\hline \multirow{2}{*}{ No } & \multicolumn{1}{|c|}{ Learning Model } & \multicolumn{2}{|c|}{ Kolmogorov-Smirnov } \\
\cline { 3 - 4 } & & Sig. & Note \\
\hline 1 & Problem Based Learning & 0.074 & Normal \\
\hline 2 & Guided Discovery & 0.057 & Normal \\
\hline 3 & Direct instruction & 0.069 & Normal \\
\hline
\end{tabular}

The homogeneity test showed that both higher order thinking and science process skills data were homogen (Table 3).

Table3. The result of homogeneity test of higher order thinking and science process skill

\begin{tabular}{|c|c|c|}
\hline & Leven's Statistic \\
\hline Variables & Sig. & Note \\
\hline Higher order thinking & 0.210 & Homogen \\
\hline Science process skill & 0.090 & Homogen \\
\hline
\end{tabular}

In order to know the effect of learning model on higher order thingking and science process skills of the student, hypothesis testing has been done by using analysis covariance (Anacova). The result of testing showed there was significat effect of learning model both on higher order thinking $(\mathrm{F}=4.371$; $\mathrm{P}=0.039)$ and science process skills of the students $(\mathrm{F}=6.106 ; \mathrm{P}=0.015)$. It means that Ha be accepted ( Table 4).

Table4. The result of Anacova test on Higher-Order Thinking and Science Process Skills

\begin{tabular}{|c|c|c|c|}
\hline Variable & \multicolumn{1}{|c|}{$\mathrm{F}_{\text {count }}$} & Sig. & \multicolumn{1}{c|}{ Note } \\
\hline Higher order thinking & 4.371 & .039 & Ha be accepted \\
\hline Science process skills & 6.106 & .015 & Ha be accepted \\
\hline
\end{tabular}

Table5. Results of Sheffe test on higher order thinking skills.

\begin{tabular}{|c|c|c|c|}
\hline \multirow{2}{*}{\multicolumn{2}{|c|}{ Learning model }} & \multicolumn{2}{|c|}{ Scheffe test } \\
\hline & & Sig. & Note \\
\hline \multirow{2}{*}{ PBL } & GD & .006 & \multirow{2}{*}{ Significantly different } \\
\hline & DI & .000 & \\
\hline \multirow{2}{*}{ GD } & PBL & .006 & \multirow{2}{*}{ Significantly different } \\
\hline & DI & .001 & \\
\hline \multirow{2}{*}{ DI } & PBL & .000 & \multirow{2}{*}{ Significantly different } \\
\hline & GD & .001 & \\
\hline
\end{tabular}

Based on multiple comparison test that has been done by using Scheffe test, the result showed there was very significantly differences of student higher order thinking who taught by problem based learning, guided discovery and direct instruction models (Table 5). These results showed that problem 
based learning, guided discovery and direct instruction gave different effect on students' higher order thinking skills.

The result of Scheffe test on comparison of science process skill of the student showed there was significantly differences just only between problem based learning class and direct instruction class (Table 6).

Table6. Result of Scheffe test on science process skills.

\begin{tabular}{|c|c|c|c|}
\hline \multicolumn{2}{|c|}{ Learning model } & \multicolumn{2}{c|}{ Scheffe test } \\
\cline { 2 - 4 } & GD & Sig. & Note \\
\cline { 2 - 4 } \multirow{2}{*}{ PBL } & DI & .064 & Not significantly different \\
\cline { 2 - 4 } & PBL & .000 & Significantly different \\
\cline { 2 - 4 } GD & DI & .064 & Not significantly different \\
\cline { 2 - 4 } & .091 & Not significantly different \\
\hline
\end{tabular}

In order to know the effect of learning model on three aspects of higher order thinking, the result of statistic test showed there was significat effect of learning model on analyze, evaluation and creation of higher order thinking (Table 7).

Table7. Statistic test result on the effect of learning model on each aspect of higher order thinking

\begin{tabular}{|c|c|c|c|c|c|c|}
\hline \multirow{2}{*}{ Aspect } & \multicolumn{7}{|c|}{ The mean score of the learning model } \\
\cline { 2 - 7 } & PBL & GD & DI & $F_{\text {count }}$ & P & Note \\
\hline Analyze & 32.32 & 30.11 & 24.65 & 1.70 & .037 & Significantly \\
\hline Evaluation & 29.11 & 26.71 & 20.45 & 2.13 & .041 & Significantly \\
\hline Creation & 24.18 & 22.81 & 13.11 & 2.09 & .021 & Significantly \\
\hline
\end{tabular}

Table 8. Statistic test result on the effect of learning model on each aspect of science process skills

\begin{tabular}{|c|c|c|c|c|c|c|}
\hline \multirow{2}{*}{ Aspect } & \multicolumn{7}{|c|}{ The average value of the learning model } \\
\cline { 2 - 7 } & PBL & GD & DI & $\mathrm{F}_{\text {count }}$ & P & Note \\
\hline Observation & 10.48 & 9.83 & 6.70 & 2.59 & .011 & Significantly \\
\hline Classification & 7.55 & 7.42 & 4.51 & 2.11 & .035 & Significantly \\
\hline Prediction & 7.05 & 7.03 & 3.89 & 2.35 & .042 & Significantly \\
\hline Interpretation & 18.18 & 16.56 & 11.34 & 1.19 & .020 & Significantly \\
\hline Asking question & 7.50 & 7.50 & 5.76 & 1.11 & .276 & $\begin{array}{c}\text { Not } \\
\text { Significantly }\end{array}$ \\
\hline Hypothesized & 4.74 & 4.74 & 2.13 & 0.76 & .447 & $\begin{array}{c}\text { Not } \\
\text { Significantly }\end{array}$ \\
\hline $\begin{array}{c}\text { Planning the } \\
\text { experiment }\end{array}$ & 12.21 & 12.14 & 7.31 & 2.02 & .041 & Significantly \\
\hline $\begin{array}{c}\text { Apply the } \\
\text { concept }\end{array}$ & 13.08 & 12.00 & 8.56 & 1.32 & .192 & $\begin{array}{c}\text { Not } \\
\text { Significantly }\end{array}$ \\
\hline Communicate & 7.13 & 6.89 & 3.38 & 2.26 & .020 & Significantly \\
\hline
\end{tabular}

Due to the effect of learning model on nine aspects of science process skill, the result of statistic test showed there was significant effect of learning model on observation, classification, prediction, interpretation, planning experiment, and communication aspect of science process skill of the students (Table 8).

\subsection{Discussions}

Based on the research result, the higher order thinking and science process skill of the student who taught by problem based learning model was highest compared to guided discovery and direct instruction. This research finding could be explained because problem based learning in learning process has five aspects in its sintax, namely problem presentation, student organizing research, assisting student investigation, exhibiting work and problem solving evaluation. This syntax makes teachers play a role in guiding students to investigate, rather than conceptualizing students (Arends, 2007). Mugla (2011) stated that problem based learning drills the students to find their own concepts based on real life problems with inquiry skills, therefore, the model belonged to the highest level model. Furthermore, problem based learning in learning process focuses the students on the problem identify, gather information regarding the problem, propose hypotheses, and try to find the solution of the problem. In this model students have the opportunity to use their abilities to achieve the best 
competence. The presence of problem that must be solve in learning process also stimulate the competencies of students to discover new knowledge.

The findings in this research are acordance with the statement of Masek \& Sulaiman (2011) and Hemo Silver et al. (2004) who stated that the implementation of problem based learning approach in learning process can make students to have higher-order thinking skills. Meyer et al. (2004) also confirmed that if the students are able to think in higher order thinking, the students will master the science process skill. In addition, Slameto (2010) stated that problem based learning can influence student metacognition and increase the knowledge and science process sill of the students.

The highhest of higher order thinking and science process skills on the students that be taught by problem based learning compared to guided discovery and direct instruction (traditional model) as that be found in this research is in line with the research result that be conducted by Noma, et al (2016). In this case as model that be built on constructivism and active learning theories, problem based learnig can accommodate students to develop their ability to analyze, evaluate, and create something in learning process and also can maximize their ability to construct the concept definition through ideas, experiences and facts.

In comparison to the direct instruction model, guided discovery gave better effect on higher order thingking and science process skills of the student. This finding could be explained because the students who learn in guided discovery model solves the problem under the guidance of the teacher. By using worksheets, the student are directed to learn in groups, doing observation or experiment to collect data. The students are also asked to interpret the data and to communicate the result of their activities. In the learning process with guided discovery the students are invited actively to search the truth. In contrast to the problem based learning, students who learn in guided discovery are richer in knowledge and understanding. These cognitives are still belongs to lower order thingking.

As in problem based learning model, the application guided discovery model in learning process can also improve the communication skills of the students. It can occur because students are asked to find the concept during the learning process. The findings that be obtained by each student will be different because each student has a different mindset, therefore, each student must be able to convey her or his findings into the group or in the classroom. According to Dimyati and Mujiono (2010) this communication skills are needed as the basis for the solving problems.

\section{CONCLUSION}

Based on the results and discussion of this research, it is concluded that there was a significant effect of problem based learning, guide discovery and direct instruction models on high-order thinking competence and science process skills of the student at topic ecology in biology learning process. Higher order thinking and science process skills of the student who taught by problem based learning model significantly higher than the other two models (guided discovery and direct instruction models. It is recommended to use problem based learning in improving the higher order thingking and science process skill of the student in biology learning especially at topic ecology.

\section{REFERENCES}

[1] Abrari, N, A, I., et al., (2012). Pengaruh Penerapan Metode Guided Discovery Learning terhadap Keterampilan Proses Sains Siswa Kelas X SMA Negeri 1 Teras Boyolali Tahun Pelajaran 2011/2012 [The Effect of Implementation of Guided Discovery Learning Method on Science Process Skills of Grade X Students of SMA Negeri 1 Teras Boyolali Lesson Year 2011/2012]. Jurnal Pendidikan Biologi. 4(2): 4452 .

[2] Arends, R.I. (2007). Learning to Teach $7^{\text {th }}$ Edition. USA: The McGraw-Hill Companies. Inc.

[3] Chatib, M. (2012). Orangtuanya Manusia [His parents are human]. Bandung: Kaifa

[4] Dimyati dan Mujiono. 2010. Belajar dan Pembalajaran [Study and Learning]. Rineka Cipta. Jakarta

[5] Hemo-Silver, C.E., et al., (2004). Psycological Tools in Problem-based Learning, in Enhancing Thinking through Problem-based Learning Approaches. Singapore: Thomson Learning.

[6] Heong, Y. M., et al., (2012). The Level of Marzano Higher Order Thinking Skills for Generating Ideas. Procedia - Social and Behavioral Sciences, 59, 197-203.

[7] Kemdikbud. (2013). Kurikulum 2013 SMA/MA (Madrasah Aliyah) [Curriculum 2013 of High School (SMA)/ Madrasah Aliyah (MA)]. Jakarta: Directorate General of Primary and Secondary Education.

[8] Kemdikbud. (2014). Pembelajaran Scientific [Scientific Learning]. Ministry of Education and Culture. Retrieved from:kemdikbud. go.id. 
[9] Manurung, B. et al. (2017). Developing ecology and environment learning materials of scientific literacy skills and local potencial for Indonesia students. International Journal of Humanities Social Sciences and Education (IJHSSE), 4/7, 84-93.

[10] Masek, A., Sulaiman, Y. (2011). The Effect of Problem Based Learning on Critical Thinking Ability: A Theoretical and Empirical Review. International Review of Social Sciences and Humanities. Vol.2, No.1 (2011), pp. 215-221 www.irssh.com ISSN 2248-9010 (Online), ISSN 2250-0715

[11] Melani, R. (2012). Pengaruh Metode Guided Discovery Learning Terhadap Sikap Ilmiah dan Hasil Belajar Kognitif Biologi SMA SMA Negeri 7 Surakarta Tahun Pelajaran 2011/2012 [The Effect of Guided Discovery Learning Method on Scientific Attitudes and Learning Outcomes of Cognitive Biology SMA SMA 7 Surakarta Lesson Year 2011/2012]. Tesis. FKIP Universitas Sebelas Maret. Surakarta.

[12] Meyers, B.E. et al., (2004). Assessing Agriculture Teacher' Capacity for Teaching Science Integrated Process Skills. Journal of Southern Agricultural Education Research, 54/1, 74-84.

[13] Mugla. (2011). Overviews on Inquiry Based and Problem Based Learning Methods. Journal of Educational Science, ISSN 1308-8971.

[14] Noma, L. D., et al., (2016). PBL untuk Meningkatkan Kemampuan Berpikir Tingkat Tinggi Siswa Kelas X SMA [PBL to Increase Higher order Thinking of High School Students of SMA X]. Jurnal Bioedukasi, 9/2, 62-66.

[15] OECD (2016) PISA 2015, PISA Results in Focus. www.oecd.org/pisa/pisa-2015-results-in-focus.pdf.

[16] Rustaman, N.Y. (2010). Literasi sains siswa Indonesia [Indonesian Student Scientific Literacy]. Article.

[17] Samatowo, U.(2010). Bagaimana Pembelajaran IPA di Sekolah Dasar [How to Study Science in Primary School]. Jakarta: Depdiknas.

[18] Slameto.(2010). Belajar dan Faktor-Faktor yang Mempengaruhinya [Learning and Factors Affecting It]. Jakarta: Rineka Cipta.

[19] Suryosubroto. 2002. Proses Belajar Mengajar di Sekolah [Teaching and Learning Process in School]. Jakarta: Rineka Cipta.

[20] Sugiyono. (2011). Metode Penelitian Kuantitatif Kualitatif dan R\&D [Qualitative Quantitative Research Methods and R \& D]. Bandung: Alfabeta.

\section{AUTHORS' BIOGRAPHY}



Haryati, S.Pd, is a biology education postgraduate student at Postgraduate Programe of Universitas Negeri Medan (Medan State University), Medan, North Sumatera, Post code 20221, Indonesia. She obtained her Sarjana Degree (S1) in Biology Education from Universitas Islam Negeri Medan, her obtaining Master Programe in Biology Education on Universitas Negeri Medan.

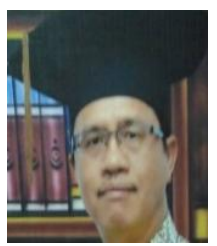

Dr. rer. nat. Binari Manurung, Drs, M.Si, is a professor in bioecology of the Biology Department at Graduate and Postgraduate Programe of Universitas Negeri Medan (Medan State University), Medan, North Sumatera, Post code 20221, Indonesia. He obtained his Sarjana Degree (S1) in Biology Education from IKIP Medan, his Master Degree (S2) in Biology from ITB Bandung and his Doctor Degree (S3) in biology from Martin-Luther University of Halle-Witten berg, Halle (Saale), Germany. Hi mailing adress is binarimanurung@unimed.ac.id (Corresponding author).

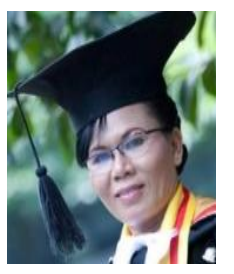

Dr. Tumiur Gultom, S.P, M.P, is a lecturer at Graduate and Postgraduate Programe of Universitas Negeri Medan (Medan State University), Medan, North Sumatera, Post code 20221, Indonesia. She obtained her Sarjana Degree (S1) in Agriculture from Universitas Pattimura, her Master Degree (S2)in Agriculture from Universitas Sumatera Utara, Medan (North Sumatera University), her Doctor Degree (S3) in Genetics and Plant Breeding from UGM Yogyakarta.

Citation: Haryati, Binari Manurung, Tumiur Gultom. "The Effect of Learning Model on Higher order Thinking and Student Science Process Skills In Ecology." International Journal of Humanities Social Sciences and Education (IJHSSE), vol 4, no. 10, 2017, pp. 150-155. doi:http://dx.doi.org/10.20431/2349-0381.0410018.

Copyright: (c) 2017 Authors. This is an open-access article distributed under the terms of the Creative Commons Attribution License, which permits unrestricted use, distribution, and reproduction in any medium, provided the original author and source are credited. 